\title{
Potential Economic Effects of Energy Efficiency Improvement in Serbia ${ }^{1}$
}

UDK: $330.341: 620.9(497.11) ; 620.91$

DOI: 10.7595/management.fon.2012.0039

\begin{abstract}
This paper is based on the analysis of energy efficiency improvement measures and potential economic effects in Serbia that should be implemented in the forthcoming period. The prevalent research is focused on determination of economic effects and decrease of trade account deficit.
\end{abstract}

Keywords: energy efficiency, improvement, models, effects

\section{Introduction}

The trade account imbalances are a long-term problem that creates pressure on the increase of a country's foreign debt. In the time of the economic crisis it is necessary to assess various measures that might contribute to a decrease in Serbian macroeconomic imbalances. The main goal of this article is to conduct a research on potential macroeconomic effects of energy efficiency improvement.

The structure of the energy sector implies the need for continuous investment. The targeted allocation of funds in energy efficiency and effectiveness improvement can create positive effects. In the Serbian case the attention should be directed at the improvement of energy efficiency through energy saving measures. The experience of other countries shows that one of the easiest measures to introduce is the efficient use of heating energy for households.

Serbia is a net importer of energy. In the urban areas district heating systems use imported natural gas and the situation is different in the cases of individual households that use both imported energy and also the energy produced in Serbia. The purpose of this paper is to present the potential positive macroeconomic effects related to energy efficiency improvement in Serbia.

\section{The energy efficiency improvement financing instruments}

Even though the return on investment in the case of energy efficiency improvement is high (3-8 years), the implementation of a large scale of projects can lead to an exorbitant overall sum. The rough estimates show that a refurbishment of the complete building stock in Serbia, in order to achieve the minimum standards of energy efficiency, will cost several billion euros. The expectations that these types of projects could be financed solely by the final consumers, state or local budgets are not realistic. The development of a proper energy efficiency financing models needs to be based on the causal relation between costs and benefits. If the highest benefits are expected to be generated by the final consumer then it is logical to assume that budgetary support is justified.

The answer to this dilemma is more obvious in the economic crisis setting. The state interest in energy efficiency improvement is very obvious, but the disposable budgetary funds are limited. Besides the macro- 
economic effects that would be assessed later, it is clear that any energy savings can lead to several positive effects:

1. The pressure on the state and/or local budgets could be decreased through a decrease in spending of electric energy or district heating price subsidy (direct or indirect) and the consolidated budgetary balance could thus be improved;

2. The household disposable income would increase in relation to the saved heating energy; the National Statistics Bureau poll (2012) shows that an average household spends $15.3 \%$ of their income on energy (the largest share), water and other running costs;

3. The possibility that Serbia (once again) becomes an electric energy net exporter or to decrease import of energy would contribute to trade account improvement.

In the pre-crisis period Serbia should have taken more deliberate steps in the implementation of energy efficiency projects. Even if these projects had been financed through international loans, it can be concluded that the most of these loans might have already been repaid. Currently, the direct financing by the state can hardly be imagined and thus a comparative analysis by Rajkiewicz (2009) of alternative financial instruments applied in 10 EU countries (Germany, Denmark, The Netherlands, Poland, the Czech Republic, Slovakia, Lithuania, Latvia, Bulgaria and Estonia) is more than valuable.

The common approach in the energy efficiency improvement implementation in these countries was a combination of different financial instruments and adjustment of the financing model to disposable funds in the budget and the potential project co-financing by citizens. The application of different models is interconnected with the various objectives. A mixed public/private model (state and banks) has the goal to maximize the number of potential energy efficiency measures and amplify the scale and scope of implementation. On the other hand, subsidies, tax credits and grants to low-income families are examples of redistributive fiscal policy that enables implementation of energy efficiency measures in the cases when citizens do not hold significant personal savings or/and are not eligible for taking a bank loan.

These experiences provide an important conclusion for the further implementation of energy efficiency improvement in Serbia. Undoubtedly, the state must introduce different financial instruments and especially include adequate support programmes for vulnerable groups in order to enable a smooth refurbishment implementation in the multihousehold buildings. Hence it is necessary to combine the basic bank loan model with the various supplemental financial instruments (subsidies, tax credits and grants) in order to maximize the household coverage and to obtain optimum implementation.

\section{The potential energy efficiency improvement effects}

The inefficient use of energy creates a myriad of negative effects in the cases of economies that do not have sufficient supply of resources and that are highly dependent on energy imports. The analysis of electric energy consumption shows that positive effects will occur if the insulation of buildings is improved. These positive effects are visible both on the household and the macro levels.

In the previous decades the quality of heat insulation in Serbia was far below the optimum level and the citizens were not in a position to invest in the improvement of insulation due to the precarious economic conditions. However, it should be highlighted that the present system offers no proper incentives for energy efficiency improvement. The electric energy price is subsidized and that creates a bias towards using electric energy for heating purposes even though this solution is not rational and does not contribute to energy efficiency improvement. The second important misalignment is the prevailing system of district heating payment based upon the normative per square meter scheme. This system does not provide the needed incentives for the households to save the energy and consequently decrease the heating invoice. In this system the households also do not have an incentive to invest in insulation with the aim to decrease the energy consumption. Finally, the introduction of a new payment system based upon the real consumption is a pre-requisite for the implementation of energy efficiency projects. 
The change of the payment scheme does not provide an answer to the important question of the energy efficiency improvement financing model. The basic question is the extent and role of the state and local levels in energy efficiency projects.

The ultimate goal of the energy efficiency improvement is to provide positive effects and benefits for all involved parties in the process. The state role is extremely important because it can hardly be expected that the desired effects could solely be a result of incentives and a spontaneous citizens' actions.

Golove and Eto (1996) highlight three reasons for state intervention in the energy efficiency improvement process:

1. Decrease in negative market effects;

2. Decrease in the transaction costs;

3. Helping individuals to help themselves.

In the previous period the scale and scope of energy efficiency improvement projects were insufficient. Some of the projects were implemented through donations of the former European Agency for Reconstruction (between 2005 and 2008 CARDS program). The World Bank loan provided support for energy efficiency improvement of public buildings (health and education sector facilities). In addition, the economic crisis impeded any large-scale energy efficiency investment by citizens and thus implicitly it can be concluded that greater role of state is needed in the forthcoming period. The effectiveness of certain measures is derived by comparing potential positive effects and the related costs. The implementation of a project should start only if the expected benefits and positive effects are higher than the costs.

Also, it is worth mentioning that as Serbia is on the brink of EU accession negotiations, the EU acquis has to be taken into account when adopting any new strategies and initiatives. The energy efficiency improvement has an important place within the EU acquis and a number of regulations, directives and communications have been adopted:

1. Council Directive 93/76/EEC of 13 September 1993 to limit carbon dioxide emissions by improving energy efficiency (SAVE), Official Journal L 237, 22/09/1993 P. 0028 - 0030

2. Directive 2002/91/EC of the European Parliament and of the Council of 16 December 2002 on the energy performance of buildings, Official Journal L 001, 04/01/2003 P. 0065 - 0071

3. Communication from the Commission, Action Plan for Energy Efficiency: Realising the Potential, COM(2006)545 final

4. Brussels European Council 8/9 March 2007, Presidency Conclusions, 7224/1/07 REV 1

5. Directive 2010/31/EU of the European Parliament and of the Council of 19 may 2010 on the energy performance of buildings (recast), Official Journal L 153, 18/06/2010, P. 13-35

6. Communication from the Commission - Energy efficiency: delivering the $20 \%$ target, COM/2008/0772 final

Nilsson (2006) states that the issue of energy efficiency is also important in the context of accession negotiations with the EU: implicitly (in negotiating ratio of renewable resources and energy dependency in general), but also explicitly (during negotiations on state aid). This and other papers have led us to a conclusion that benefits, financial and otherwise, highly surpass any costs related to energy efficiency improvement programs, hand in hand with very good return on investment rate. It is a paradox why no large-scale energy efficiency improvement programs are ongoing in Serbia, a country highly dependent on energy imports.

Serbia maintains a high foreign trade deficit and low import coverage ratio. Energy imports are also quite high, as domestic production of energy is not sufficient to satisfy the needs of industry and consumers. Therefore, by increasing energy efficiency, Serbia would also decrease its imports and improve the trade balance. Consequently, this would relieve the pressure on the dinar (RSD) exchange rate, improving its stability.

In the period 2001-2008 significant amounts of foreign currency have been obtained through privatization of state-owned companies, so despite the trade deficit, real exchange rate even appreciated against the euro at one point. Also, foreign direct investment (FDI) and remittances have also had a positive influence on balance of payment and have, in turn, provided one more source for financing the current account deficit. Yet, with the onset of the economic crisis in 2008, privatization revenues and FDI have decreased, therefore the state had to finance this deficit through public debt increase in order to prevent sharp economic decline and to maintain a relative stability of the exchange rate. 
This analysis leads to a conclusion that Serbia needs to take up loans year after year in order to finance the current account deficit. In other words, Serbia addresses the consequence, rather than cause of the problem. And the cause itself, from the energy efficiency point of view, is an irrational use of energy and large energy imports.

It would be unfounded to expect that public expenditures, the most favorable way of financing energy efficiency projects, would substantially increase in the forthcoming period. The alternative way of financing these programmess through loans seems to be entirely justifiable and sustainable. Sustainability is easily identifiable in public buildings, where energy consumption would decrease, and state institutions would pay less for the supply - naturally, that would only be the case if energy consumption is charged per actual spending, rather that the square footage of the building. On the other hand, the state would be able to cofinance or subsidize the interest rate for energy efficiency improvement projects in commercial and residential buildings, as well as in individual housing. Both individuals and companies could repay the investment through the money saved with improved energy efficiency. Nominally, they would still pay the same amount of money based on the normative criteria - square footage - while the savings from the lower energy consumption would create a reserve in comparison to their historical bills and new real consumption. This reserve would be in turn used to repay the investment and thus the whole system would become self-sustained in a matter of years.

Similar programs have been applied in other transition economies, and they are in most cases in their final stages - this was analyzed in detail by Rajkiewicz (2009). Unquestionably, Serbia is already faced with the need to spend energy (more) rationally, having in mind not only increasing prices of energy imports, but also increased domestic demand for it. Laustsen (2008) shows that potential savings could be quite significant especially in the low-efficiency type of buildings. Energy consumption, with appropriate improvements, could be reduced by $55-60 \%$.

An exact amount of energy spent for air-conditioning (cooling) is more difficult to measure. Yet, this is becoming more important as energy spending during summer months begins to play a more significant role in the energy balance of the country. Thermal insulation of the space in order to improve energy efficiency in terms of heating can only decrease the amount of energy needed for cooling during the summer, although it is still unclear by how much.

Energy efficiency improvement projects are both capital and labor-intensive. Apart from the construction industry, these projects create new jobs for engineers and architects that design solutions for energy efficiency improvements, and act as auditors for these projects. Comparative analysis shows that audits at the same time serve as a guarantee to state or municipal fund that improvements will lead to adequate savings in energy consumption. The number of new jobs created by these initiatives might reach 10-15,000, depending on the scope of the projects, i.e. funds available. This estimate is based on similar experiences from the countries that have or planned to implement such projects, e.g. USA and Poland, which were analyzed by Wei et al. (2010).

Measuring of exact effects that countrywide implementation would have on the environment is most certainly not amongst goals of this paper, but is a worthy subject for further research. Nevertheless, the effects of improving energy efficiency on the environment have to be positive, but their scope is difficult to determine. Many environmental effects are "invisible", while others are more holistic than economic - such as those that are used in public health researches. In the process of EU accession, environment is a critical chapter, having in mind that it is one of the most expensive and, at a first glance, "unprofitable" chapters. This is why every improvement in this aspect is significant.

Finally, energy efficiency improvement financed by public debt increase would not have positive effects only on trade balance, i.e. decrease of energy imports. Throughout the process, local companies and labour force would increase economic growth and improve budgetary stance by revenue increase. It would especially stimulate the demand for construction material, which is mostly made locally. Therefore, this scenario calls for not only energy efficiency improvement, but also for increase in GDP and decrease in unemployment. During economic crisis, these measures have a countercyclical impact and contribute to economy stabilization. Also, investment into energy efficiency improvement is a productive way of spending public expenditures that, apart from already mentioned effects, reduces atmospheric emissions and improves environmental image of the country. 
This paper demonstrates different elements of the process of energy efficiency improvement and provides a general review of existing problems and potential positive effects. It analyzes possible financial instruments that programmes might use and discusses comparative practices in the European Union member states. Finally, the paper discusses potential positive macroeconomic effects that these programmes might yield in Serbia in detail - decrease in trade deficit, increase in employment rate and increase in gross domestic product. These effects are all positive and energy efficiency programmes might become one of the new pillars of sustainable and dynamic economic growth.

\section{REFERENCES}

[1] National Bureau of Statistics, Republic of Serbia, Republički zavod za statistiku (2012). Saopštenje LP11 - Anketa o potrošnji domaćinstava, no. 091, year LXII. Belgrade.

[2] Rajkiewicz A. (2009), The financial models for energy efficient retrofitting of residential buildings in 10 selected European countries, Paper presented at the Green Building Conference, Beijing.

[3] Golove, W.H. i Eto, J. H. (1996). Market Barriers to Energy Efficiency: A Critical Reappraisal of the Rationale for Public Policies to Promote Energy Efficiency, Berkeley: National Laboratory, UC Berkeley.

[4] Nilsson L.J., Pisarek, M., Buriak, J., Oniszk-Popławska, A., Bucko, P., Ericsson, K., Jaworski, L. (2006). Energy policy and the role of bioenergy in Poland. Energy Policy, 34(15), 2263-2278.

[5] Laustsen, J. (2008). Energy Efficiency Requirements in Building Codes, Energy Efficiency Policies for New Buildings, Paris: International Energy Agency.

[6] Wei, M., Patadia, S., Kammen, D.M. (2010). Putting renewables and energy efficiency to work: How many jobs can the clean energy industry generate in the U.S.? Energy Policy, 38(2), 919-931.

Receieved: October 2012.

Accepted: December 2012.

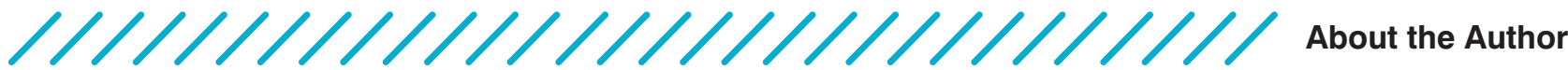

\section{Milos Eric
University Singidunum of Belgrade, Faculty of Economics, Finance and Administration}

Milos Eric is a teaching assistant at the Faculty of Economics, Finance and Administration - FEFA in Belgrade, for the courses European Integration and Economic Development. Eric holds a M.Sc. degree in European Integration and Public Management. He also researches energy efficiency, corporate social responsibility, public management and e-commerce. Erić has worked as a consultant for The World Bank and the German International Cooperation (GIZ) on projects related to education finance and financial model development for energy efficient retrofitting. He authored

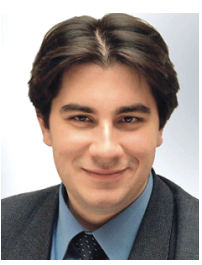
or co-authored several studies and articles.

Mihajlo Babin

University Singidunum of Belgrade, Faculty of Economics, Finance and Administration

Mihajlo Babin, (MSc) is a teaching assistant at the Macroeconomics course at the Faculty of Economics, Finance and Administration (FEFA). He graduated at the University of Novi Sad Law

Faculty in 2005 and obtained a Masters degree in Economics at the FEFA in 2008, having completed a masters thesis on "The Impact of Fiscal Policy on Maintenance of Macroeconomic Stability." As a student, he was elected to the position of Student Vice-Rector of the University of Novi Sad (2002-2004) and a member of Student Union of Serbia Executive Board (2005). He has worked as a consultant of the World Bank on pre-university education financing since 2009 . He has been actively involved in the process of higher education reform in Serbia, participating in numerous Tempus projects and in the national Higher Education Reform Experts Team between 2008 and 2010. He is one of co-authors of the Serbian Strategy of Education Development until 2020 and continues to be involved in education policy research. He also works as consultant of GIZ (Deutsche Gesellschaft für Internationale Zusammenarbeit) on energy efficiency financing models since 2011. 